\title{
Insights into Angiogenesis in Non-Small Cell Lung Cancer: Molecular Mechanisms, Polymorphic Genes, and Targeted Therapies
}

\author{
Ramon Andrade de Mello*,1,5, Bruno M. Costa ${ }^{2}$, Rui M. Reis ${ }^{2,3}$ and Venceslau Hespanhol ${ }^{4,5,6}$
}

\begin{abstract}
${ }^{I}$ Department of Medical Oncology, Portuguese Oncology Institute - Porto, Rua Dr. António Bernardino de Almeida, 4200-072, Porto, Portugal; ${ }^{2}$ Life and Health Sciences Research Institute (ICVS), School of Health Sciences, University of Minho, Campus de Gualtar, 4710-057, Braga, Portugal; ${ }^{3}$ Molecular Oncology Research Center, Barretos Cancer Hospital, Rua Antenor Duarte Vilella, 1331, CEP: 14784-400, Barretos-SP, Brazil; ${ }^{4}$ Service of Pneumology, Hospital São João, Alameda Prof. Hernani Monteiro, 4200-319, Porto, Portugal; ${ }^{5}$ Department of Medicine, Faculty of Medicine, University of Porto, Alameda Prof. Hernani Monteiro, 4200-319, Porto, Portugal; ${ }^{6}$ Director of Therapeutic and Complementary Diagnostic Methods Unit of Hospital São João, Alameda Prof. Hernani Monteiro, 4200-319, Porto, Portugal
\end{abstract}

Received: May 29, 2011; Accepted: June 16, 2011; Revised: July 28, 2011

\begin{abstract}
Lung cancer is a highly prevalent disease worldwide. Currently, there are more than 150 million patients with lung cancer in the world, with more than 1 million new cases diagnosed per year. Tumoral angiogenesis is an important hallmark of this disease, but despite being extensively studied, the complete angiogenic mechanisms are not fully elucidated. Recent studies have reported a correlation between pharmacological inhibition of these angiogenic mechanisms and improvement of overall survival in lung cancer patients, mainly for those in advanced stages. The family of vascular endothelial growth factor (VEGF) proteins has critical roles in tumoral angiogenesis. An interaction between VEGF-A and VEGF receptor 2 (VEGFR-2) is the main pathway of activation and maintenance of angiogenesis. In tumors, this process is intimately correlative with progression and metastasis. Some studies suggested that serum levels of VEGF are higher in patients with lung cancer, especially in some types of non-small cell lung cancer (NSCLC). Other studies revealed that genetic polymorphisms of VEGF correlate with susceptibility, prognosis, and therapeutic response of some patients with NSCLC. This paper aims to review the impact of angiogenesis, especially on VEGF pathways, in NSCLC, and highlights the relevance of known and new patents disclosed of anti-angiogenic therapies in these patients.
\end{abstract}

Keywords: Angiogenesis, antineoplastic drug combination, biological markers, neovascularization, non-small cell lung cancer, pathology, polymorphism, vascular endothelial growth factor.

\section{REVIEW CRITERIA}

A systematic search was made in four important data bases: PubMed (www.pubmed.com), Scopus (www.scopus. com), Freepatentsonline (www.freepatentsonline.com) and Directory of Open Access Journals (www.doaj.org), with the following terms: "VEGF polymorphisms and lung cancer"; "antiangiogenic chemotherapy"; "angiogenesis mechanisms and lung cancer"; "angiogenesis and VEGF polymorphisms"; "VEGF drugs"; "VEGF polymorphisms and lung cancer prognosis". Studies dated between 1971 and 2011 were selected and evaluated. Case reports were not considered.

\section{INTRODUCTION}

Lung cancer is a disease with high mortality and morbidity, currently affecting more than 1 million people worldwide [1]. In 2006, approximately $12 \%$ of all cancer cases were

\footnotetext{
*Address correspondence to this author at the Department of Medical Oncology, Portuguese Oncology Institute - Porto, Rua Dr António Bernardino de Almeida, 4200-072, Porto, Portugal; Tel: + 351225084 000. Ext. 7323; Cell: + 351912040 770; Fax: + 351225 084010;

E-mail: ramondemello@gmail.com
}

diagnosed as lung cancer (LC) [2]. Non-small cell lung cancer (NSCLC) is the most common of LC types, accounting for more than $80 \%$ of all new cases in North America [1,2]. It is an extremely lethal malignancy: all histological types have a 5-year survival rate of only $\sim 15 \%[3,4]$. Histologically, the major subtypes are: adenocarcinoma (the most frequent), squamous cell carcinoma, and large cell carcinoma [5]. Cigarette smoking is related with almost $87 \%$ of lung cancer-related deaths $[1,6]$. Evaluations of population patterns in smoking prevalence indicate that, in coming years, LC rates will probably decrease in Western countries due to lifestyle changes (mostly due to anti-smoking campaigns) [6]. Nevertheless, other factors account for cancer susceptibility, such as gender, ethnicity, radon exposure, clinical antecedents of lung tuberculosis, and occupational lung disease $[2,7]$. Lung carcinogenesis is influenced by the cell's ability to repair DNA lesions induced by external agents, such as tobacco and nitrosamines that initiate the carcinogenic process [4]. These genetic lesions will affect genes that regulate cancer hallmark mechanisms: uncontrolled cellular proliferation; escape from programmed cell death; unlimited replicative potential; tissue invasion and metastization; and genesis of new blood vessels from pre-existent vasculature (angiogenesis) [8]. Therefore, the angiogenic process is a 
paramount feature of NSCLC and the introduction of targeted therapies directed at key molecules of this process, like bevacizumab, a monoclonal antibody against vascular endothelial growth factor (VEGF), have shown great benefits in NSCLC patient treatment, especially when the malignancy is in advanced stages [8-11]. This paper aims to review the impact of angiogenesis, especially of VEGF pathways, in NSCLC, the relevance of polymorphisms in angiogenesisrelated genes, and discuss the impact of known and new patents of anti-angiogenic therapies on these patients.

\section{ANGIOGENIC MECHANISMS AND VEGF FAM- ILY}

\section{Mechanisms of Tumor Vessel Creation Through VEGF Pathway}

The creation of new tumor vessels influences not only the progression but also LC clinical behavior [12]. It is therefore fundamental to understand such mechanisms in order to acquire a better insight of the physiopathology and potential targeting treatments of this disease [12]. Since 1971, when Judah Folkman published his innovative hypothesis on tumoral vascularization [13], angiogenesis has been progressively considered responsible for the evolution of many can- cer types $[12,14]$. Folkman suggested that tumors above 2 $\mathrm{mm}$ would need new blood vessels in order to develop and grow, and predicted the existence of a tumor angiogenic factor responsible for inducing genesis of such vessels [15]. Currently, we know that the VEGF family is the main driver of this process, comprising six members: VEGF-A, -B, -C, $\mathrm{D}$, and -E and placental growth factor (PIGF) [16]. VEGF-A is the most important member and it is responsible for physiologic and pathologic mechanisms of angiogenesis [12]. Normally, it acts through binding with VEGF receptor 2 (VEGFR-2) generating a cascade of intracellular signaling, leading to activation of transcription factors in the nucleus that will ultimately lead to new vessel formation [10] as shown in Fig. (1). VEGF-A is a glycoprotein transcribed by a gene located on chromosome 6 (6p21.3). VEGF-A, or simply VEGF, exists in 6 isoforms categorized by the length of amino acid chains, $\mathrm{VEGF}_{121}, \mathrm{VEGF}_{145}, \mathrm{VEGF}_{165}, \mathrm{VEGF}_{183}$, $\mathrm{VEGF}_{189}$, and $\mathrm{VEGF}_{206}$. In vivo, only three isoforms have been related to angiogenesis: $\mathrm{VEGF}_{121}, \mathrm{VEGF}_{145}$, and $\mathrm{VEGF}_{165}$. The latter, with 165 amino acids, has been demonstrated to be a predominant isoform secreted by malignant and benign cells [17]. One of the major inducers of VEGF is hypoxia, which activates the hypoxia-inducible factor (HIF) $1 \alpha$ and $2 \alpha$. HIF- $1 \alpha$ function is to regulate body oxygen ho-

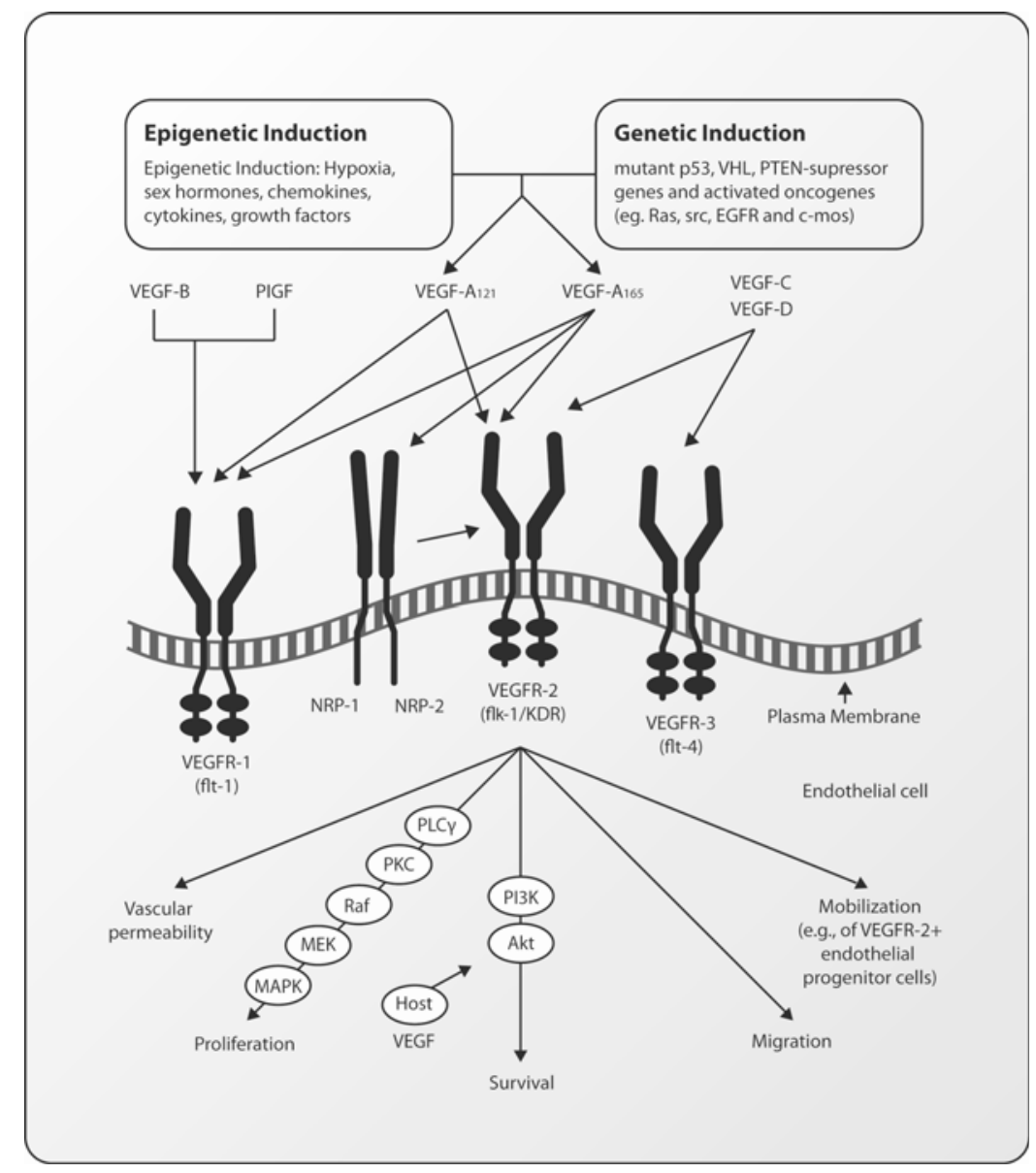

Fig. (1). Angiogenesis pathway. Adapted with permission from reference [12]. The major mediator of angiogenesis is VEGF, which circulates basically in two isoforms, VEGF-A $\mathrm{A}_{121}$ and VEGF-A $\mathrm{A}_{165}$. Many factors, both environmental and genetic, may influence VEGF expression. The binding of VEGF-A to VEGFR-2, followed by the dimerization of the receptor, leads to a cascade of signaling pathways responsible for the many steps of tumor progression: vascular proliferation, cell proliferation, cell survival and migration. 
meostasis and it is produced through a cis-acting sequence required to increase erythropoietin gene transcription in response to hypoxia [18]. HIF-1 $\alpha$ is responsible for activating the transcription of genes encoding important signaling proteins shown in Table 1, such as angiogenic factors, cellular surface receptors, and extracellular matrix proteins, thus promoting the first steps towards new vessel genesis [12, 18]. Paracrine mechanisms generated through VEGF production in tumor cells may also influence angiogenesis pathways, but those cells cannot adequately respond to the stimulus if they do not have enough cell membrane receptors for that purpose. Paradoxically, endothelial cells recruited during angiogenesis produce great amount of receptors, but produce little or no VEGF ligand. In this context, the amount of VEGF necessary to propel angiogenesis comes from several host cells in human body, like platelets, smooth muscle cells, and stromal cells, which, together, produce the necessary amounts of VEGF for angiogenesis to begin [19-21]. These vessels are significantly different from normal vasculature and do not have the same function. The structural heterogeneity of the new vasculature contributes to diversified behavior in each cancer regarding growth and tumor development [22] Table 2.

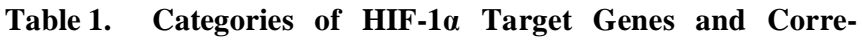
sponding Proteins.

\begin{tabular}{|c|c|}
\hline Gene Category & Transcribed Protein \\
\hline \multirow{8}{*}{$\begin{array}{l}\text { Angiogenic growth } \\
\text { factors }\end{array}$} & VEGF \\
\hline & PDGF \\
\hline & Prokineticin \\
\hline & Placental growth factor \\
\hline & Erythropoietin \\
\hline & Adrenomedulin \\
\hline & Endothelin \\
\hline & Angiopoietin 1 and 2 \\
\hline \multirow{4}{*}{$\begin{array}{l}\text { Cellular surface } \\
\text { receptors and en- } \\
\text { zymes }\end{array}$} & $\alpha_{1 \beta}$-Adrenergic receptor \\
\hline & Chemokine receptor \\
\hline & Transferring receptor \\
\hline & VEGFR-2 \\
\hline \multirow{3}{*}{$\begin{array}{l}\text { Extracellular matrix } \\
\text { proteins }\end{array}$} & Matrix metalloproteinae 2 \\
\hline & $\begin{array}{l}\text { Collagen } \mathrm{V} \alpha 1 \text {-subunit } \\
\text { Fibronectin } 1\end{array}$ \\
\hline & Cathepsin D \\
\hline \multirow[t]{3}{*}{ Cytoskeletal protein } & Ketarin 14,19 and 18 \\
\hline & Vimentin \\
\hline & \\
\hline
\end{tabular}

Abbreviations: VEGF, vascular endothelial growth factor; PDGF, platelet-derived growth factor; VEGFR, VEGF receptor.

\section{VEGF Family}

The other VEGFs family members are important for many diverse mechanisms of new vessel creation. The VEGF-B and PIGF act through VEGFR-1 in angiogenesis and in vasculogenesis. Although this receptor has higher affinity to VEGF than VEGFR-2, the interaction between VEGF-B and VEGFR-1 does not have good expression in angiogenesis pathways and its role remains unclear at this time [12]. The VEGF-C [3] and its close homolog, VEGF-D [20], influence lymphangiogenesis, through VEGFR-2 and VEGFR-3, and are also important in tumor metastization [3, 20]. The VEGF-E concurrent to VEGF-A, VEGF-B and PIGF acts by binding to neutrophilin 1, a nonkinase receptor expressed in vascular endothelium, neurons and tumor cells, potentiating VEGF-A's binding to VEGFR-2, thus promoting the first steps of angiogenesis [16].

\section{Notch-Delta-Like Ligand 4 (Dll4) Pathways}

Recently, another pathway has proven to be very important for angiogenesis, the notch-delta-like ligand 4 (D114) pathway $[23,24]$. The Notch membrane receptors are necessary in order to generate stimuli that signal important intracellular mechanisms [23]. The Dll4/Notch pathway acts by controlling the stimulus of angiogenesis [12, 23, 24]. Some studies suggest that tumors that depend on VEGF are able to induce the expression of D114 in endothelial cells and negatively regulate the vascular growth as a mechanism to control the angiogenic rate [23]. These signaling pathways act as brake mechanisms for the production of excessive amounts of blood vessels, promoting therefore the stabilization of an angiogenic process [23]. Therefore, if there is a blockade in the Notch/Dll4 pathway, this negative feedback will be destroyed and in consequence an excessive and unorganized production of blood vessels will take place favoring tumor progression [12]. Even so, these vessels are structurally abnormal and do not possess a good tissue perfusion, leading to tumoral hypoxia $[12,23]$.

\section{VEGF Prognostic Value}

The high expression and activity of VEGF has been observed in $30-40 \%$ of NSCLC [10]. Over the last decade, several studies have reported that VEGF influences NSCLC tumor behavior [3, 9, 10, 14, 25-28]. An immunohistochemical study of 102 NSCLC patients reported a higher expression of VEGF-A in adenocarcinomas when compared to squamous cell carcinomas [25]. However, VEGF-A expression was not associated with NSCLC prognosis [25]. Recently, another study [9] enrolling 134 patients diagnosed with NSCLC, evaluated the plasma levels of total VEGF during the treatment with platinum-based chemotherapy. The patient plasma VEGF baseline cut off value considered in this study was $275.2 \mathrm{pg} / \mathrm{mL}$, but it could not be related with overall survival (OS). Nevertheless, this study showed that patients in remission had a significant reduction of plasma VEGF levels in subsequent chemotherapy cycles, which suggested the utility of VEGF as a predictive biomarker in this type of patient [9]. Another study with 118 NSCLC patients showed that patients who present serum VEGF levels $\leq 630 \mathrm{pg} / \mathrm{mL}$ had a significant OS increase as compared to those with higher levels $(p=0.04)$ [29]. It is important to 
Table 2. Differences between Normal and Tumor Vasculature.

\begin{tabular}{|l|l|}
\hline Normal Vasculature & Tumor Vasculature \\
\hline \hline Organized & Disorganized \\
\hline Evenly distributed & Unevenly distributed \\
\hline Uniform & Shaped twisted \\
\hline Nonpermeable & Leaky \\
\hline Vascular pressure is greater than interstitial pressure & Vascular pressure is similar to tumor interstitial pressure \\
\hline Properly matured & Immature \\
\hline Supporting cells present (e.g., pericytes) & Absence of supporting cells \\
\hline Appropriate membrane protein expression & Inappropriate membrane protein expression \\
\hline Independent of cell survival factors & Dependent on cell survival factors (e.g., VEGF) \\
\hline Homogenous oxygenation of tissue within $\mathrm{O}_{2}$ diffusion limit & Focal hypoxic and anoxic regions \\
\hline
\end{tabular}

Abbreviations: VEGF, vascular endothelial growth factor.

note that many factors may influence the results of the previously discussed studies, namely the isoform of VEGF that was quantified, or whether the total VEGF is measured, or even the collecting environment, storage and tubes used for venipuncture. The use of serum levels (and not plasma levels obtained from EDTA tubes) is recommended, processed until 1 hour after venipuncture and stored after centrifugation at $-80^{\circ} \mathrm{C}[10]$. Overall, several studies have shown that serum VEGF can be an important and practical biomarker for the follow up of patients with lung cancer, allowing the possibility to individualize chemotherapy and perhaps predict the aggressiveness of several histological types [9, 10, 14, 24]. In 2010, Heymach et al. [30] studied 31 cytokines in 33 early stage NSCLC patients treated with pazopanib. They reported the important role of interleukine 4 and soluble VEGFR2 in tumor shrinkage, thus suggesting the central role of angiogenic biomarkers in tumor response [30]. In the E4599 phase II and phase III trials, many other biomarkers were evaluated, and good prognostic value of intracellular adhesion molecule 1 (ICAM-1) was found [31]. In the same study, serum VEGF was found to be a good predictive biomarker for patients treated with bevacizumab, but did not significantly correlate with OS [31]. Also, they suggested ICAM-1 as a strong prognostic marker for overall survival, and the circulating endothelial progenitor cells as a promising marker due to their responsiveness to anti-angiogenic agents.

\section{ANTI-ANGIOGENIC TARGETED THERAPIES AND NEW PATENTS}

For a long time, conventional chemotherapy, based mainly on platinum, has not shown satisfactory results in the treatment of lung cancer, especially in advanced stages, with an average OS under 10 months after diagnosis $[1,28]$. Since then, targeted therapies, especially those associated with anti-angiogenic mechanisms such as tyrosine kinase inhibitors (TKI) and monoclonal antibodies, have shown some improvement in OS for several cancer types, including advanced stages of NSCLC Table 3 [11, 22, 28, 32-36]. TKIs are the compounds that selectively target the intracellular tyrosine kinase domain of receptors and act by competing with the ATP-binding site, thereby inhibiting the tyrosine phosphorylation and blocking the signaling pathways. The monoclonal antibodies usually bind to ligands and decrease the angiogenic activity by blocking its interaction with membrane receptor cell signaling.

\section{VEGFR, EGFR and RET Multi-Target Tyrosine Kinase Inhibitors}

The increased knowledge of the molecular mechanisms underlying cancer development and progression leads to the development of specific targeted therapies against key cellular players, with outstanding results in some tumor types [3739]. Some drugs, mainly of the TKIs category, targeting the three VEGF receptors, VEGFR-1, VEGFR-2 and VEGFR-3, have been evaluated in phase II and phase III studies for their anti-angiogenic and clinical action. One example is the sorafenib, an oral anti-kinase inhibitor with anti-angiogenic and anti-proliferative activity; but it has not demonstrated clinical benefit in addition to standard chemotherapy in phase III studies [40, 41]. Another example is vandetanib, a multitarget TKI, which targets VEGFR2, epidermal growth factor receptor (EGFR) and RET, and has an improvement in progression-free survival (PFS) in phase II studies of NSCLC patients, as monotherapy or in combination therapy [36], and also when compared with gefitinib [42]. One study presented at the American Society of Clinical Oncology (ASCO) congress in 2010 confirmed vandetanib superiority PFS versus placebo in NSCLC patients, but did not demonstrate an OS benefit [43]. Currently the OS study results are not very consistent regarding this molecule, despite its benefit on PFS [44].

\section{VEGFR, EGFR, PDGF, FGF and PIGF receptors tyro- sine kinase inhibitors}

Many other TKIs target multiple receptors, as is the case with sunitinib, montesanib, and the axitinib, which block the 
activity of VEGFR-1, VEGFR-2, VEGFR-3, EGFR, and PDGF receptors. Their LC anti-tumor properties are currently being studied in phase I and phase II studies [34, 35, 45-50], but until this moment no significant data has been disclosed [51]. Nevertheless, some studies raised high expectations, like axitinib, which has proved to be a very powerful drug in a phase II study with an OS of 14.8 months [52]. The inhibition of endothelial proliferation via endostatin pathway was also recently showed to be promising. A novel invention in this field has been demonstrated to inhibit angiogenesis in mice lung cancer cells. This patent is a recombinant endostatin inhibitor (US7867975) with molecular weight between 18 to $20 \mathrm{KDa}$ and is capable of inhibiting endothelial cell proliferation in vitro [53]. Recently, patents such as BIBF 1120, have emerged in phase I and II trials as potent TKIs that simultaneously inhibit VEGFR 1-3, fibroblast growth factor receptors 1-3, and placental-derived growth factor $\alpha$ and $\beta$ [54]. In fact, the results were not enough to conclude on OS and PFS, but the drug was well tolerated when used in a continuous treatment regimen. Another invention (US7875603) showed some benefit by inhibiting VEGFR in lung cancer treatment, as such as breast, colorectal, prostate and ovarian [39]. This invention decreases angiogenic activity by blocking the VEGF receptors.

\section{EGFR Tyrosine Kinase Inhibitors}

At the end of the of 1990's, EGFR was shown to play an important role in tumor biology and behavior [55]. EGFR overexpression is present in approximately 43 to $83 \%$ of NSCLC, being more common in squamous cell carcinoma (70\%), followed by adenocarcinoma $(50 \%)$, and to a lesser extent in large cell carcinoma. This phenomenon is very rare in SCLC [55-58]. Its stimulation by external factors activates the intracellular signaling and cascades, through the downstream signaling pathway phosphoinositide 3-kinase (PIK3) regulation, $\mathrm{Akt}$ and mammalian target of rapamycin (mTOR), or through Ras-Raf-Mek pathway (MAPK), induces the expression of VEGF, and influences cellular proliferation, mobilization and angiogenesis [4, 59]. In tumor cells, it was found that the activation of cell proliferation mediated by EGFR would no longer need the external stimulus, but act independently and autonomously [55]. In the particular case of NSCLC, it was shown that the EGFR overexpression, as well as specific somatic mutations occurred in their intracellular domain with tyrosine kinase activity (between exons 18 and 21), were the factors of poor prognosis, being significantly related with stage, survival and chemotherapy response [55, 60-63]. This data led to the development and study of various substances, among which are monoclonal antibodies (e.g. cetuximab (Erbitux ${ }^{\circledR}$ ), already approved for the treatment of colorectal carcinoma, but still under study in NSCLC) and TKIs, gefitinib (Iressa ${ }^{\circledR}$ ) and erlotinib $\left(\right.$ Tarceva $\left.^{\circledR}\right)$ [55, 60, 64-67]. After, some papers [6870] started to evaluate which was the best method to assess EGFR role in the response, PFS and OS of patients with NSCLC treated with gefitinib: EGFR mutation, copy number or quantitative of EGFR assessed by Fluorescence in situ hybridization (FISH) or real-time polymerase chain reaction (PCR) or EGFR detected by immunohistochemistry. The EGFR mutation (deletion in exon 19 or L858R in exon 21) has shown high sensitive $(92 \%)$ and moderately specific
(76\%) for predicting response to EGFR TKI chemotherapy. Nowadays, this test is the preferred method for selecting patients with advanced, chemorefractory lung adenocarcinoma who are most likely to respond to erlotinib or gefitinib treatment [62]. The other methods, such as copy number by FISH or immunohistochemical positivity, may have a role for PFS predicting within an EGFR-mutated subset of patients, but they are not independently informative tests [62, 63].

Two TKI's of EGFR, gefitinib and erlotinib, are currently used for the treatment of adenocarcinoma and NSCLC. Erlotinib was approved for refractory locally advanced/metastatic NSCLC [71]; and, since May 2010, gefitinib was approved by European Medicine Agency (EMEA) for use in first line treatment of metastatic advanced NSCLC, EGFR mutation positive based on its PFS and OS benefits when compared with the carboplatin-paclitaxel-treated group $[72,73]$ and the cisplatin-docetaxel-treated group [74]. Erlotinib in April 2010 was also approved for maintenance treatment in advanced NSCLC patients with stable tumor disease based on SATURN study [63, 72, 75]. Therefore, these therapies cannot only have an anti-neoplastic, but also an anti-angiogenic activity. Currently, the therapeutically resistance mechanisms for EGFR TKI are the subjects of discussion. There are several documented resistance point mutations to gefitinib and erlotinib, such as T790M, L747S and D761Y [56, 63]. The T790M is the most common secondary resistance mutation reported, accounting for about $50 \%$ of tumor relapse from prior TKI treatment [76].

\section{The Role MET Inhibitors Drugs}

In the last three decades, MET proto-oncogene was discovered that encodes the high affinity cell surface receptor (c-MET) for hepatocyte growth factor (HGF) and also controls carcinogenesis steps, including cell growth, proliferation, invasion and protection from apoptosis [77]. Recently, MET inhibitor patents are emerging as a new class of target therapies that promise good results in NSCLC patients [78]. The dual EGFR-MET inhibition [79] or VEGF/KDR receptor-HGF/c-MET dual inhibitor (US7790729) [78] are good strategies to improve anti-angiogenic approach by circumventing the ability of tumor cells overcome VEGF inhibition alone or overcoming MET-mediated resistance to EGFR inhibitors [78, 79]. In 2010, at the annual ASCO meeting, Wakelee et al. reported a new patent, XL184, that is an oral potent inhibitor of MET, VEGFR2 and RET in association with erlotinib in NSCLC patients. Its use is encouraged mainly in patients with erlotinib resistant and EGFRT790M and MET amplification [80]. Another recent patent, ARQ197, is a selective non ATP competitive inhibitor of cMET that, when combined with erlotinib in treatment of second/third line EGFR inhibition, a naïve NSCLC increase of PFS was shown, mainly among patients with non-squamous histology, K-RAS mutations, and EGFR wild-type status [79]. In 2011, a new patent (US787211) provided a good weapon to suppress tumor growth toward c-MET pathways. This invention acts using RNA interference (RNAi) technology and adenovirus carrying siRNA (Ad met siRNA) target sequences that substantially reduces MET expression in human tumors cells. Ad met siRNA kills cancer cells by inducing apoptosis. In vivo, intra-tumoral infection with c-met 
siRNA adenovirus vectors produces significant reduction in tumor growth [81]. Thus, this might be another choice in future to use associated with EGFR TKIs chemotherapies.

\section{Anti-Angiogenic Monoclonal Antibody: Bevacizumab}

Currently, drugs like bevacizumab act basically by reducing the interactions between VEGF and its receptors, diminishing the intracellular signaling that triggers the growth of new vessels, therefore improving the OS and also the PFS $[14,36]$. Recently, some clinical trials have been developed aiming at demonstrating the effectiveness of new specific anti-angiogenic drugs for the improvement of the NSCLC approach as reported in Table $\mathbf{3}[11,32-36,41,42,46-50$, 52, 71, 82-87]. In 2006, the Eastern Cooperative Oncology Group (ECOG) in a phase III trial (ECOG 4599) involving 878 patients diagnosed with advanced stage NSCLC showed [33] that adding bevacizumab, a monoclonal anti-body against VEGF, to the conventional chemotherapy protocols based on platinum, significantly increases the OS of 10.3 months in a group treated only with chemotherapy for 12.3 months in a group that underwent chemotherapy and bevacizumab (hazard ratio $=0.79, \mathrm{p}=0.003$ ). There was also an increase in PFS from 4.5 months to 6.2 months in the group with bevacizumab (hazard ratio $=0.66, \mathrm{p}<0.001$ ), and the therapeutic response also increased [33]. This monoclonal antibody was later approved by the FDA in 2006 for advanced NSCLC treatment [1]. Nevertheless, the same study [33] demonstrated that this treatment must be carefully considered in order to avoid the risk of thromboembolic events and even fatal hemorrhagic events more frequently associated to central tumors with squamous histology [11,33]. The AVAiL phase III trial showed an arguable benefit of adding bevacizumab to conventional therapy in advanced NSCLC patients when the PFS improvement was not clinically significant, but the design could not compare with the best dosage $(7.5 \mathrm{mg} / \mathrm{kg}$ or $15 \mathrm{mg} / \mathrm{kg}$ each 3 weeks) [11]. Recently, the final analysis of AVAiL resulted in still minor clinical PFS improvement when bevacizumab is combined with gemcitabine and carboplatinum, and without improvement in OS [88]. The ATLAS and PASSPORT studies demonstrated that it could be safely used in patients with brain metastasis [89] since they are first treated with brain radiotherapy and without progression evidence by imaging studies after four weeks since beginning treatment $[90,91]$. Currently, bevacizumab is the only anti-angiogenic target therapy approved by FDA for NSCLC patients, especially in those aged less than 70 years old, stage IV and performance status zero to one [1, 90].

\section{New Patents in Anti-Angiogenic Monoclonal Antibody Field}

In the sequence, new patents such as VC300 (US7740844) [92], US7691977 [93], AMG102 [94], Met$\mathrm{Mab}$ [95], $\mathrm{VEGF}_{165} \mathrm{~b}$ (US7820178) [96] and US7875704 [97] emerged as promising inventions in the angiogenesis of monoclonal antibodies field as also shown in Table $\mathbf{4}$ and Fig. (2). VC300 is a recent monoclonal antibody that binds to amino acid residues $\mathrm{Asn}_{100}$ and $\mathrm{Lys}_{107}$ in human VEGF neutralizing its activity. This invention can be prepared by recombinant technology and it can be incorporated into pharmaceutical compositions suitable for an administration to a subject [92]. Another interesting new US patent (US7691977) of the last year was novel antibodies polypeptide sequence capable of binding the rodent and human VEGF with Kd values within 10 fold of each value wherein they inhibit the binding of VEGF to VEGFR. The antibody comprises a complementarity-determining region $\mathrm{H} 1$ (CDRH1) comprising the amino acid sequence ASWIH, a CDR$\mathrm{H} 2$ comprising the amino acid sequence AIYPYSGYTNYADSVKG, a CDR-H3 comprising the amino acid sequence WGHSTSPWAMDY, a CDR-L1 comprising the amino acid sequence RASQDVSTAVA, a CDR-L2 comprising the amino acid sequence SASFLYS, and a CDR-L3 comprising the amino acid sequence QQSYTTPPT. Further evaluations are warranted in this field in order to assess its feasibility in solid tumor, especially NSCLC [93]. In a phase Ib study, the AMG102, a monoclonal antibody against HGF, showed a possible benefit in solid tumor dimension reduction when combined with bevacizumab, but further evaluation with this patent is warranted [94]. Also, the monoclonal antibody acting directly against MET showed good clinical results. MetMab (Genentech) is a human recombinant antagonist of HGF-MET signaling pathway, demonstrated to be well tolerated in association with bevacizumab and effective in a phase Ib trial [95] and also with minor PFS improvement $[98,99]$.

Furthermore, as result of differentially splicing into a previously undescribed exon, exon 9, a new VEGF isoform in kidney cells was discovered with anti-angiogenic activity (called $\mathrm{VEGF}_{165} \mathrm{~b}$, with 165 polypeptides sequence). This novel isoform may have an importance in future cancer treatment protocols [96]. The PlGF is another molecule that modulates angiogenesis. In 2011, a new patent provided a monoclonal antibody that inhibit PIGF binding with its receptor that can be used to significantly reduce the tumorigenicity steps with a decrease of side effects caused by an inhibition of physiological angiogenesis [97]. Thus, as molecular mechanisms of tumor biology are elucidated, new therapeutic possibilities are developed in order to improve the treatments for the NSCLC patients, as monotherapy or in association with the existent chemotherapy protocols [100].

\section{GENETIC POLYMORPHISMS RELATED TO THE ANGIOGENESIS PATHWAYS}

The human $V E G F$ gene has more than 15 single nucleotide polymorphisms (SNPs) identified to date [101-103]. Due to the central roles of VEGF in angiogenesis, some of these gene polymorphisms have been recently studied in the context of different tumor types, including breast cancer [104], malignant melanoma [105], prostate cancer [106], and lung cancer [101, 103, 107-112]. Importantly, particular polymorphic variants have been shown to be functional [113-115] (i.e. they correlate with VEGF production), and have already been associated with tumor risk, angiogenesis, vascular density, and prognosis [101, 103-112]. Table 5 summarizes the major conclusions of studies addressing the relevance of individual VEGF polymorphisms in the context of lung cancer, particularly as putative risk factors for developing lung cancer and mediators of VEGF levels, tumor behavior, and patient prognosis. Table $\mathbf{6}$ summarizes the studies addressing 
Table 3. Summary of Clinical Trials Evaluating Anti-Angiogenic Therapy in NSCLC Patients.

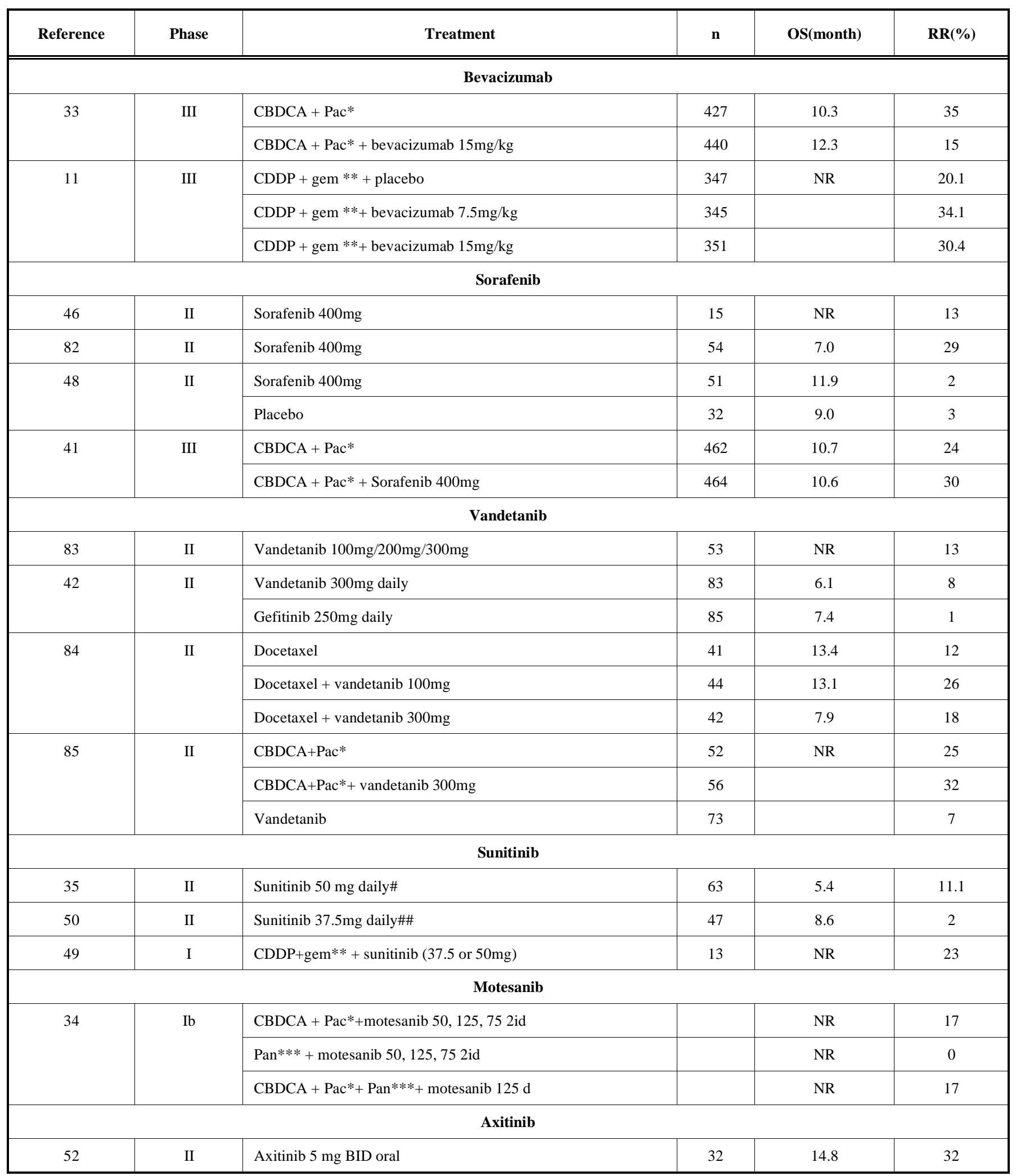

Abbreviations: $\mathrm{n}$, number of patients; $\mathrm{OS}=$ overall survival; $\mathrm{RR}=$ response rate; $\mathrm{NR}=$ not reported; $* \mathrm{CBDCA}+$ Pac: Carboplatin + paclitaxel; $* * \mathrm{CDDP}+$ gem: Cisplantin + gemcitabin; *** Panitumumab each every 21 days cycle; \#sunitinib administered daily for 4 weeks of 6 weeks cycle; \#\#Sunitinib administered daily continuously for 4 weeks cycles. 


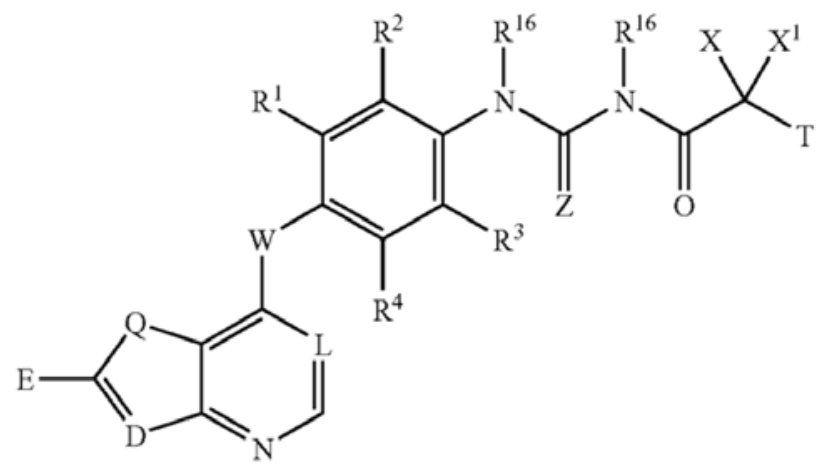

Fig. (2). Formula of the US7790729 patent. It is a compound that inhibits VEGFR and c-MET signaling.

Table 4. Summary of New Relevant Patents on Anti-Angiogenic Drugs.

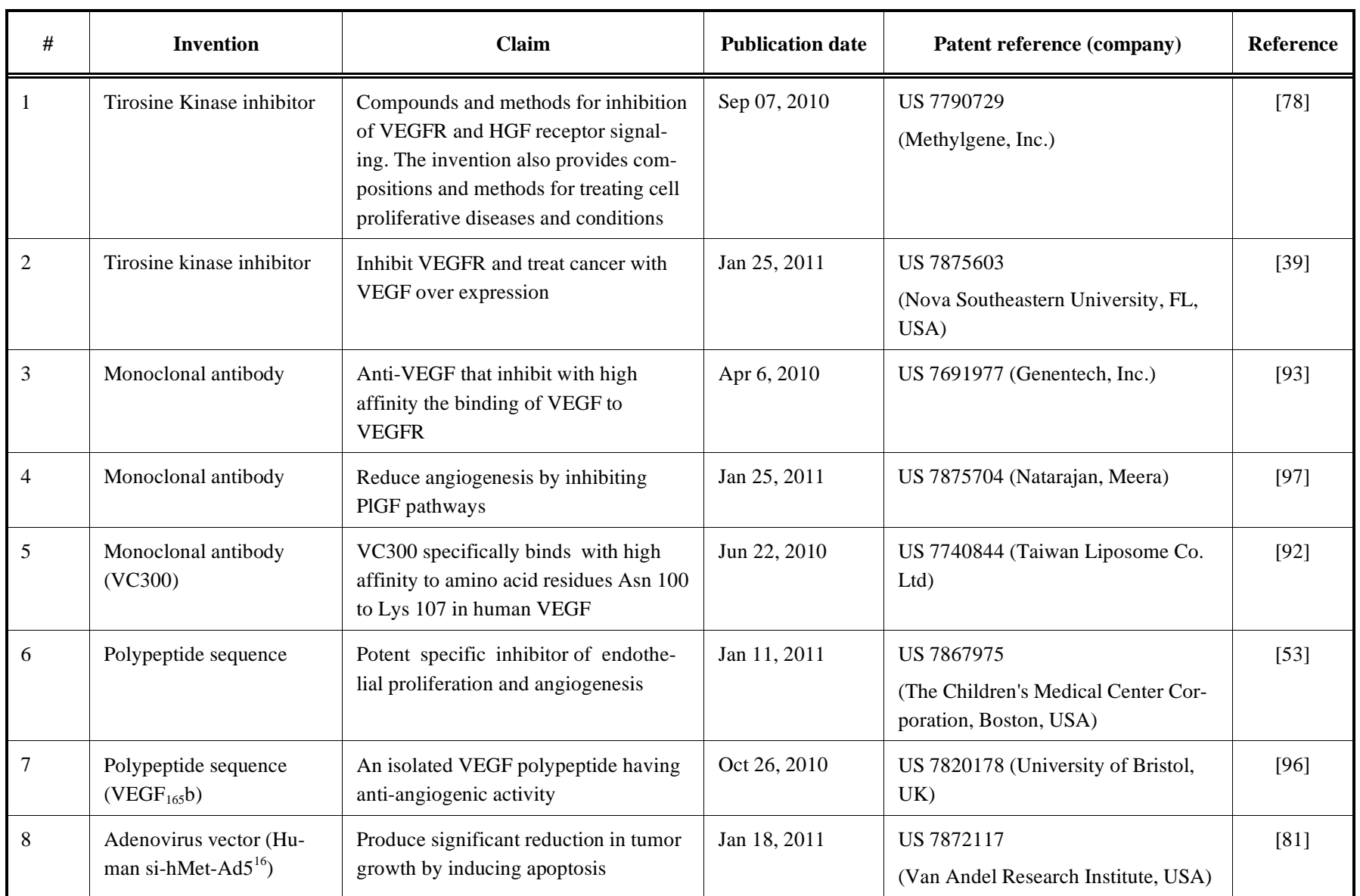

Abbreviations: VEGF, vascular endothelial growth factor; VEGFR, VEGF receptor; HGF, hepatocyte growth factor; CDR, complementarity determining region; USA, United States of America; UK, United Kingdom; PIGF, placental growth factor

the contribution of $V E G F$ haplotypes (combinations of specific allelic variants in different polymorphism) in LC. This body of data emphasizes that some $V E G F$ SNP variants may be LC biomarkers; however, some conflicting results have been reported in different studies, as some studies report statistically significant associations between $V E G F$ polymorphic variants and tumor risk/behavior, while others fail to show this- see Table $\mathbf{5}$. This may be due to differences in study design and analysis, small sample sizes, different eth- nic backgrounds across studies, and experimental and procedural variations to assess, for example, $V E G F$ gene variants, VEGF levels, and patient outcome. It is also clear that, despite the unquestionable relevance of VEGF in tumors, particularly highly angiogenic neoplasms like LC, and the use of anti-angiogenic therapies in some of these tumors, there is still a very limited number of studies addressing the relevance of VEGF polymorphisms in LC. Future well-designed, large, prospective studies are warranted to clearly establish 
Table 5. Summary of VEGF Polymorphisms in Lung Cancer.

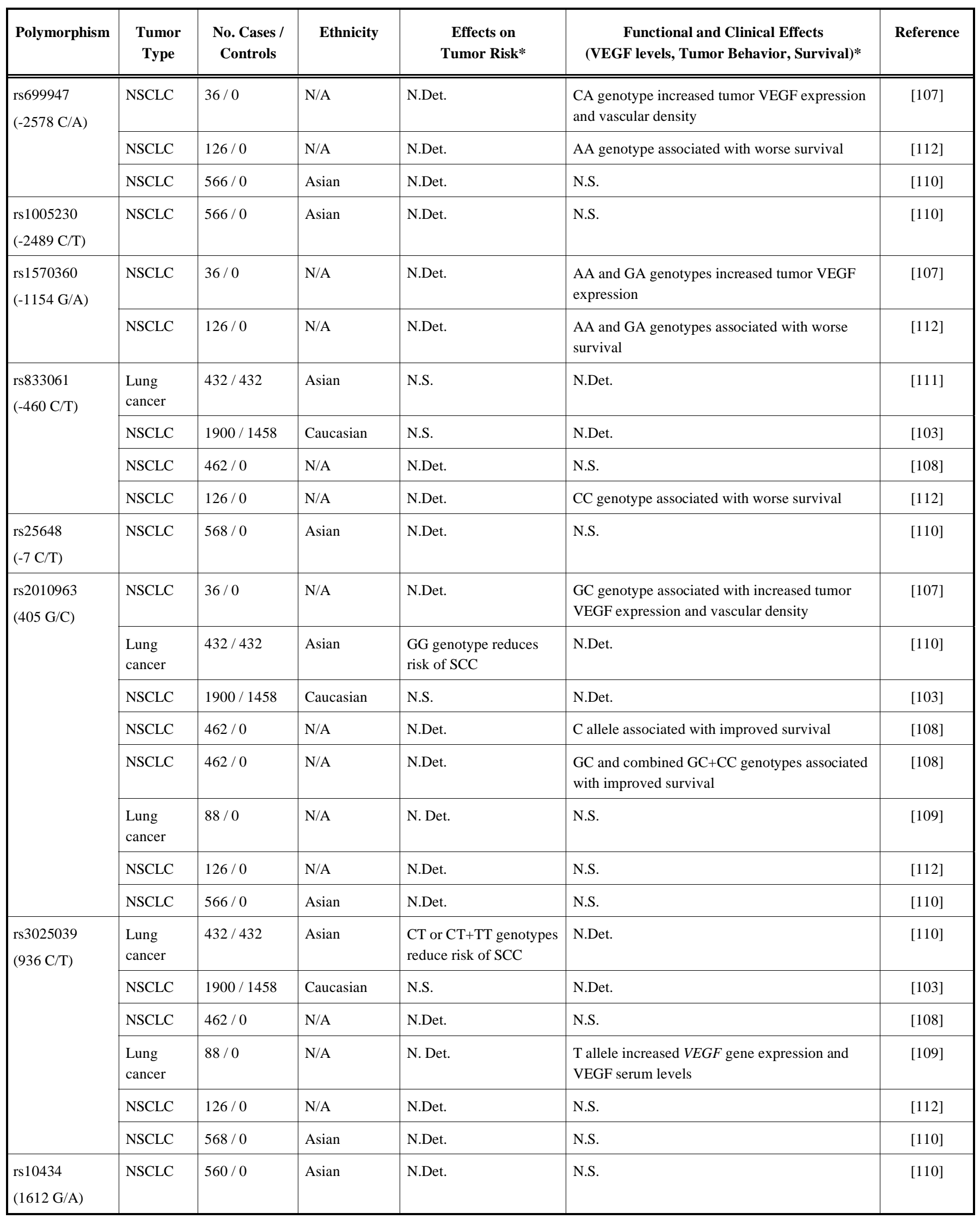


(Table 5) Contd.....

\begin{tabular}{|c|c|c|c|c|c|c|}
\hline Polymorphism & $\begin{array}{l}\text { Tumor } \\
\text { Type }\end{array}$ & $\begin{array}{l}\text { No. Cases / } \\
\text { Controls }\end{array}$ & Ethnicity & $\begin{array}{c}\text { Effects on } \\
\text { Tumor Risk* }\end{array}$ & $\begin{array}{c}\text { Functional and Clinical Effects } \\
\text { (VEGF levels, Tumor Behavior, Survival)* }\end{array}$ & Reference \\
\hline $\begin{array}{l}\text { rs } 833069 \text { (in- } \\
\text { tron } 2 \text { G/A) }\end{array}$ & NSCLC & $560 / 0$ & Asian & N.Det. & N.S. & [110] \\
\hline $\begin{array}{l}\text { rs } 833070 \text { (in- } \\
\text { tron } 2 \text { G/A) }\end{array}$ & NSCLC & $560 / 0$ & Asian & N.Det. & N.S. & [110] \\
\hline $\begin{array}{l}\text { rs3024994 } \\
\text { (intron } 2 \mathrm{C} / \mathrm{T} \text { ) }\end{array}$ & NSCLC & $568 / 0$ & Asian & N.Det. & N.S. & [110] \\
\hline $\begin{array}{l}\text { rs } 3025010 \\
\text { (intron } 5 \mathrm{C} / \mathrm{T} \text { ) }\end{array}$ & NSCLC & $567 / 0$ & Asian & N.Det. & N.S. & [110] \\
\hline $\begin{array}{l}\text { rs3025035 } \\
\text { (intron } 7 \mathrm{C} / \mathrm{T} \text { ) }\end{array}$ & NSCLC & $568 / 0$ & Asian & N.Det. & N.S. & [110] \\
\hline $\begin{array}{l}\text { rs3025040 } \\
\text { (3'-UTR T/C) }\end{array}$ & NSCLC & $568 / 0$ & Asian & N.Det. & N.S. & [110] \\
\hline $\begin{array}{l}\text { rs3025053 } \\
\text { (3'-UTR G/A) }\end{array}$ & NSCLC & $568 / 0$ & Asian & N.Det. & N.S. & [110] \\
\hline
\end{tabular}

* - Significant differences were considered when $\mathrm{P}<0.05$.

Abbreviations: NSCLC, non-small cell lung cancer; SCC, small cell carcinoma; N/A, not available; N.Det., not determined; N.S., not significant.

Table 6. Summary of VEGF Haplotypes in Lung Cancer.

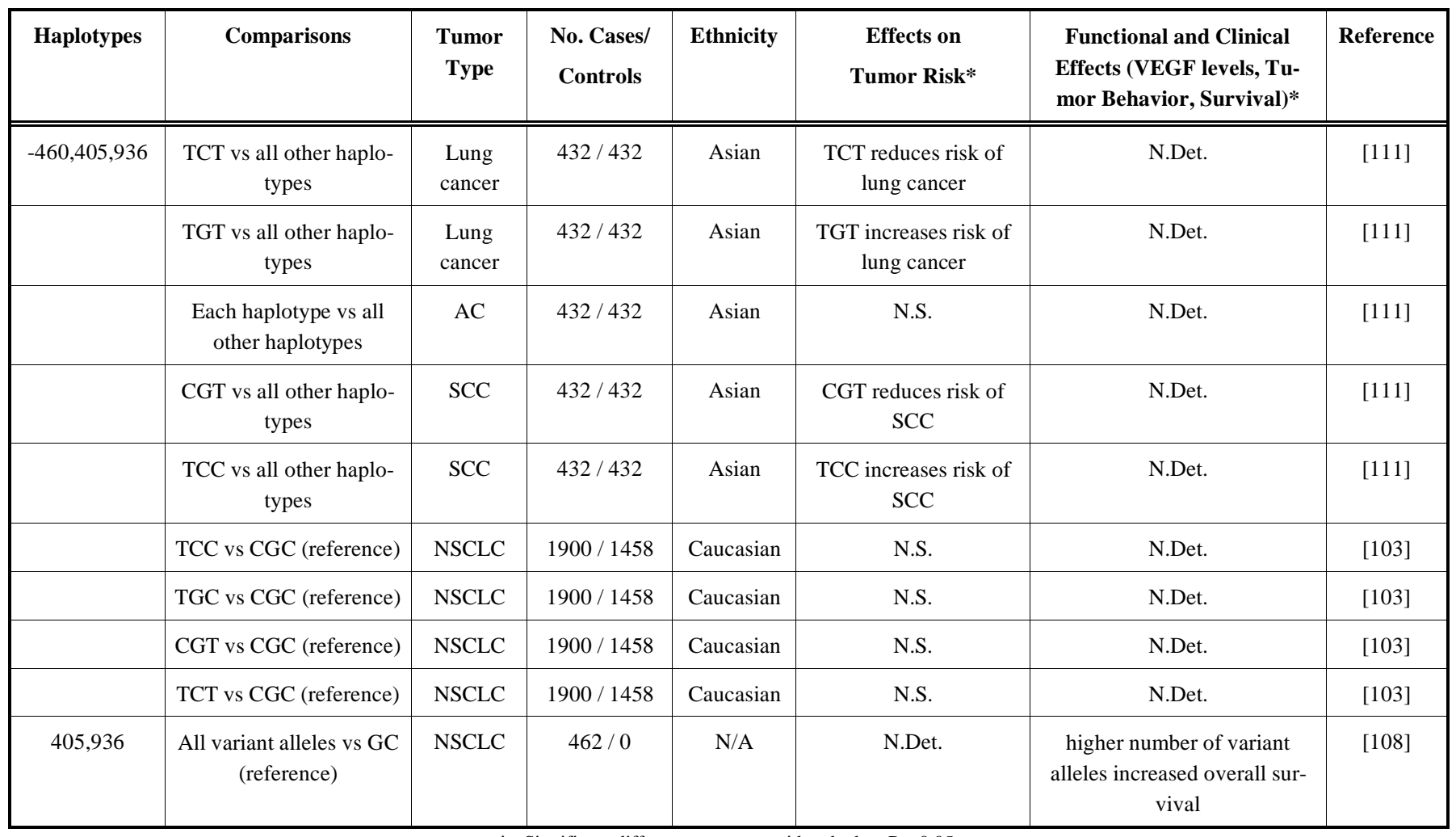

* - Significant differences were considered when $\mathrm{P}<0.05$.

Abbreviations: NSCLC, non-small cell lung cancer; AC, adenocarcinoma; SCC, small cell carcinoma; N/A, not available; N.Det., not determined; N.S., not significant.

the biological and clinical implications of these polymorphisms in different types of LC, particularly how they affect tumor risk, progression, and response to therapies, especially those targeting angiogenesis-related molecules.

\section{CURRENT \& FUTURE DEVELOPMENTS}

Currently, many efforts are underway in order to develop new therapeutic strategies against LC based on its molecular 
and clinical features. The treatment of NSCLC patients with anti-angiogenic agents, like bevacizumab, together with other agents [116], like gefitinib and erlotinib for EGFRpositive tumors, has demonstrated how these fundamental new targeted therapies are in order to improve survival and the quality of life of these patients.

Combined chemotherapy composed by molecular therapies as well as conventional chemotherapy have shown better results in patients with NSCLC because they concurrently and synergistically act in different molecular pathways [32, 116]. Many clinical trials [11, 32-35, 41, 42, 46-50, 52, 71, 82-85, 87] have reported the beneficial impact of these combined therapies as demonstrated in Table $\mathbf{3}$, commonly assessed at the levels of OS and PFS [32, 117]. The VEGF, through either its serum levels [9] or its tumoral levels, has shown evidence of being a putative prognostic marker in NSCLC [28]. Several VEGF genetic polymorphisms related directly or indirectly to angiogenesis like the $+936 \mathrm{C} / \mathrm{T}$ [109], the +405 G/C [108], and the - 460 T/C [111] polymorphism extend a certain impact to the prognosis and/or the risk level for NSCLC patients. However, currently there are still no satisfactory biomarkers capable of correlating to risk, to therapeutic response, or to prognosis of NSCLC patients, which is currently a challenge in the field of oncology. It is extremely important to better understand anti-cancer pharmacogenomics in order to improve clinical practice. For this reason, more studies are necessary for a better understanding of the illness mechanisms and for the improvement of future therapeutic protocols, making it possible to evaluate, with reasonable accuracy and low expense, what type of treatment is best for each patient, as well as the potential NSCLC risk development.

\section{ACKNOWLEDGEMENTS}

We would like to thank Dr. Miguel Nunes from Department of Informatic of Faculty of Medicine of the University of Porto, Porto, Portugal, for his help in technical support, and Prof. Henrique Queiroga, Department of Pneumology of Faculty of Medicine of the University of Porto, Porto, Portugal for his critical contribution in this manuscript review.

\section{CONFLICT OF INTEREST}

The authors declare that they not have any competing interest.

\section{ABBREVIATIONS USED}

$\begin{array}{lll}\text { VEGF } & = & \text { Vascular endothelial growth factor } \\ \text { LC } & = & \text { Lung cancer } \\ \text { NSCLC } & = & \text { Non small cell lung cancer } \\ \text { PIGF } & = & \text { Placental growth factor } \\ \text { VEGFR } & = & \text { VEGF receptor } \\ \text { HIF } & = & \text { Hypoxia inducible factor } \\ \text { Dll4 } & = & \text { Delta-like ligand } 4 \\ \text { OS } & = & \text { Overall survival } \\ \text { PFS } & = & \text { Progression free survival }\end{array}$

\begin{tabular}{|c|c|c|}
\hline EDTA & $=$ & Ethylenediamine tetraacetic acid \\
\hline ICAM-1 & $=$ & Intracellular cell adhesion molecule 1 \\
\hline TKI & $=$ & Tyrosine kinase inhibitor \\
\hline EGFR & $=$ & Epigermal growth factor receptor \\
\hline FISH & $=$ & Fluorescence in situ hybridization \\
\hline ASCO & $=$ & American society of clinical oncology \\
\hline PIK3 & $=$ & Phosphoinositide 3-kinase \\
\hline mTOR & $=$ & Mammalian target of rapamycin \\
\hline EMEA & $=$ & European Medicine Agency \\
\hline US & $=$ & United States \\
\hline FDA & $=$ & Food and drugs administration \\
\hline HGF & $=$ & Hepatocyte growth factor \\
\hline KDR receptor & $=$ & Kinase insert domain receptor \\
\hline CDR & $=$ & Complementarity-determining region \\
\hline $\mathrm{V}_{\mathrm{h}}$ & $=$ & Variable region \\
\hline SNP & $=$ & Single nucleotide polymorphism \\
\hline
\end{tabular}

\section{REFERENCES}

[1] Schrump D, Giaccone G, Kelsey K, Marks L. Non Small Cell Lung Cancer. In: DeVita V, Lawrence T, Rosenberg S, Weinberg R, DePinho R, editors. DeVita, Hellman, and Rosenberg's Cancer: Principles \& Practice of Oncology. $8^{\text {th }}$ ed. Philadelphia: Lippincott Williams \& Wilkins 2008: 896-939.

[2] Fauci A, Braunwald E, Kasper D, Hauser S, Longo D, Jameson J, et al. Harrison's Principles of Internal Medicine. $17^{\text {th }}$ ed. New York McGraw-Hill Medical Publishing Division 2008: 551-62.

[3] Guo X, Chen Y, Xu Z, Qian Y, Yu X. Prognostic significance of VEGF-C expression in correlation with COX-2, lymphatic microvessel density, and clinicopathologic characteristics in human non-small cell lung cancer. Acta Biochim Biophys Sin (Shanghai) 2009; 41(3): 217-22.

[4] Herbst R, Heymach J, Lippman S. Molecular origins of cancer. N Engl J Med 2008; 359 (13): 1367-80.

[5] Abeloff MD, Armitage JO, Niederhuber JE, Kastan MB, McKenna WG. Abeloff's Clinical Oncology. $4^{\text {th }}$ ed. Philadelphia: Churchill Livingstone; 2008: 1327-46.

[6] Alberg A, Brock M, Samet J. Epidemiology of lung cancer: looking to the future. J Clin Oncol 2005; 23(14): 3175-85.

[7] Sculier J, Chansky K, Crowley J, Van Meerbeeck J, Goldstraw P. The impact of additional prognostic factors on survival and their relationship with the anatomical extent of disease expressed by the $6^{\text {th }}$ Edition of the TNM Classification of Malignant Tumors and the proposals for the $7^{\text {th }}$ Edition. J Thorac Oncol 2008; 3(5): 457-66.

[8] Fong K, Minna J. Molecular biology of lung cancer: Clinical implications. Clin Chest Med 2002; 23(1): 83-101.

[9] Kumar S, Guleria R, Singh V, Bharti A, Mohan A, Das B. Efficacy of plasma vascular endothelial growth factor in monitoring firstline chemotherapy in patients with advanced non-small cell lung cancer. BMC cancer 2009; 9(1): 421.

[10] Bremnes R, Camps C, Sirera R. Angiogenesis in non-small cell lung cancer: The prognostic impact of neoangiogenesis and the cytokines VEGF and bFGF in tumours and blood. Lung Cancer. 2006; 51(2): 143-58.

[11] Reck M, von Pawel J, Zatloukal P, Ramlau R, Gorbounova V, Hirsh V, et al. Phase III trial of cisplatin plus gemcitabine with either placebo or bevacizumab as first-line therapy for nonsquamous non-small-cell lung cancer: AVAil. J Clin Oncol 2009; 27(8): 1227-34.

[12] Kerbel R. Tumor angiogenesis. N Engl J Med 2008; 358(19): 2039 49. 
[13] Folkman J. Tumor Angiogenesis: From Bench to Bedside. In: Marmé D, Fusenig N, editors. Tumor Angiogenesis: Basic concepts and cancer therapy. $8^{\text {th }}$ ed. Berlin: Springer 2008: 3-28.

[14] Herbst R, Onn A, Sandler A. Angiogenesis and lung cancer: Prognostic and therapeutic implications. J Clin Oncol 2005; 23(14): 3243-46

[15] Folkman J. Tumor angiogenesis: Therapeutic implications. N Engl J Med. 1971; 285: 1182-86.

[16] Dvorak H. Vascular permeability factor/vascular endothelial growth factor: A critical cytokine in tumor angiogenesis and a potential target for diagnosis and therapy. J Clin Oncol. 2002; 20(21): 4368-80.

[17] Ferrara N, Henzel W. Pituitary follicular cells secrete a novel heparin-binding growth factor specific for vascular endothelial cells. Biochem Biophys Res Commun. 1989; 161(2): 851-58.

[18] Semenza G. Hydroxylation of HIF-1: Oxygen sensing at the molecular level. Physiology (Bethesda) 2004; 19: 176-82.

[19] Kasahara Y, Tuder R, Taraseviciene-Stewart L, Le Cras T, Abman $\mathrm{S}$, Hirth $\mathrm{P}$, et al. Inhibition of VEGF receptors causes lung cell apoptosis and emphysema. J Clin Invest 2000;106(11):1311-19.

[20] Juttner S, Wissmann C, Jons T, Vieth M, Hertel J, Gretschel S, et al. Vascular endothelial growth factor-D and its receptor VEGFR-3: Two novel independent prognostic markers in gastric adenocarcinoma. J Clin Oncol 2006; 24(2): 228-40.

[21] González R, Leyva A, Melo R, Moreira R, Pessoa C, Farias R, et al. Método para estudo in vivo da angiogênese: indução de neovascularização na córnea de coelho. Acta Cir Bras 2000; 15(3): 168-73.

[22] Duda D, Jain R, Willett C. Antiangiogenics: The potential role of integrating this novel treatment modality with chemoradiation for solid cancers. J Clin Oncol 2007; 25(26): 4033-42.

[23] Noguera-Troise I, Daly C, Papadopoulos N, Coetzee S, Boland P, Gale $\mathrm{N}$, et al. Blockade of Dll4 inhibits tumour growth by promoting non-productive angiogenesis. Nature 2006; 444(7122): 1032-37

[24] Sainson R, Harris A. Anti-Dll4 therapy: Can we block tumour growth by increasing angiogenesis? Trends Mol Med 2007; 13(9): 389-95.

[25] Bonnesen B, Pappot H, Holmstav J, Skov BG. Vascular endothelial growth factor A and vascular endothelial growth factor receptor 2 expression in non-small cell lung cancer patients: Relation to prognosis. Lung Cancer 2009; 66(3): 314-8.

[26] Yuan A, Yu C, Luh K, Chen W, Lin F, Kuo S, et al. Quantification of VEGF mRNA expression in non-small cell lung cancer using a real-time quantitative reverse transcription-PCR assay and a comparison with quantitative competitive reverse transcriptionPCR. Lab Invest 2000; 80(11): 1671-80.

[27] Jain R, Duda D, Willett C, Sahani D, Zhu A, Loeffler J, et al. Biomarkers of response and resistance to antiangiogenic therapy. Nat Rev Clin Oncol 2009; 6(6): 327-38

[28] Jubb A, Oates A, Holden S, Koeppen H. Predicting benefit from anti-angiogenic agents in malignancy. Nat Rev Cancer 2006; 6(8): 626-35.

[29] Laack E, Kohler A, Kugler C, Dierlamm T, Knuffmann C, Vohwinkel G, et al. Pretreatment serum levels of matrix metalloproteinase- 9 and vascular endothelial growth factor in nonsmall-cell lung cancer. Ann Oncol 2002; 13(10): 1550-7.

[30] Nikolinakos P, Altorki N, Yankelevitz D, Tran H, Yan S, Rajagopalan D, et al. Plasma cytokine and angiogenic factor profiling identifies markers associated with tumor shrinkage in early-stage non-small cell lung cancer patients treated with pazopanib. Cancer Res 2010; 70(6): 2171-9.

[31] Dowlati A, Gray R, Sandler A, Schiller J, Johnson D. Cell Adhesion molecules, vascular endothelial growth factor, and basic fibroblast growth factor in patients with non-small cell lung cancer treated with chemotherapy with or without bevacizumab: An Eastern Cooperative Oncology Group Study. Clin Cancer Res 2008; 14(5): 1407-12.

[32] Horn L, Sandler AB. Angiogenesis in the treatment of non-small cell lung cancer. Proc Am Thorac Soc 2009; 6(2): 206-17.

[33] Sandler A, Gray R, Perry M, Brahmer J, Schiller J, Dowlati A, et al. Paclitaxel-carboplatin alone or with bevacizumab for nonsmall-cell lung cancer. N Engl J Med 2006; 355(24): 2542-50.

[34] Blumenschein G, Reckamp K, Stephenson G, O'Rourke T, Gladish G, McGreivy J, et al. Phase 1b study of motesanib, an oral angiogenesis inhibitor, in combination with carboplatin/paclitaxel and/or panitumumab for the treatment of advanced non-small cell lung cancer. Clin Cancer Res 2010; 16(1): 279-90.

[35] Socinski M, Novello S, Brahmer J, Rosell R, Sanchez J, Belani C, et al. Multicenter, phase II trial of sunitinib in previously treated, advanced non-small-cell lung cancer. J Clin Oncol 2008; 26(4): 650-6.

[36] Hanrahan E, Lin H, Kim E, Yan S, Du D, McKee K, et al. Distinct patterns of cytokine and angiogenic factor modulation and markers of benefit for vandetanib and/or chemotherapy in patients with nonsmall-cell lung cancer. J Clin Oncol 2010; 28(2): 193-201.

[37] Oliveira P, Colaço A, Chaves R, Guedes-Pinto H, De-La-Cruz PL, Lopes C. Chemical carcinogenesis. An Acad Bras Cienc. 2007;79:593-616.

[38] Chiang A, Massague J. Molecular basis of metastasis. N Engl J Med 2008; 359(26): 2814-23.

[39] Rathinavelu, A., Dakshanamurthy, S., Pattabiraman, N. Specific inhibitors for vascular endothelial growth factor receptors. US 7875603 (2011)

[40] Hanna N, Von Pawel J, Reck M, Scagliotti G. Carboplatin/paclitaxel with/without sorafenib in chemonaive patients with stage IIIB-IV non-small cell lung cancer (NSCLC): Interim analysis (IA) results from a randomized phase III trial (ESCAPE). J Thorac Oncol 2008; 3: S268.

[41] Scagliotti G, von Pawel J, Reck M, Cupit L, Cihon F, DiMatteo S, et al. Sorafenib plus carboplatin/paclitaxel in chemonaive patients with stage IIIB-IV non-small cell lung cancer (NSCLC): Interim analysis (IA) results from the phase III, randomized, double-blind, placebo-controlled, ESCAPE (Evaluation of Sorafenib, Carboplatin, and Paclitaxel Efficacy in NSCLC) trial. J Thor Oncol 2008; 3: S97-S98.

[42] Natale R, Bodkin D, Govindan R, Sleckman B, Rizvi N, Capo A, et al. Vandetanib versus gefitinib in patients with advanced nonsmall-cell lung cancer: Results from a two-part, double-blind, randomized phase II study. J Clin Oncol 2009; 27(15): 2523-9.

[43] Lee J, Hirsh V, Park K, Qin S, Blajman C, Perng R, et al. Eds. Vandetanib versus placebo in patients with advanced non-small cell lung cancer (NSCLC) after prior therapy with an EGFR tyrosine kinase inhibitor (TKI): A randomized, double-blind phase III trial (ZEPHYR). American Society of Clinical Oncology - $10^{\text {th }}$ annual meeting, Chicago, USA, (2010).

[44] Herbst R, Sun Y, Eberhardt W, Germonpré P, Saijo N, Zhou C, et al. Vandetanib plus docetaxel versus docetaxel as second-line treatment for patients with advanced non-small-cell lung cancer (ZODIAC): A double-blind, randomised, phase 3 trial. Lancet Oncol 2010; 11(7): 619-26.

[45] Blumenschein Jr G, Gatzemeier U, Fossella F, Stewart D, Cupit L, Cihon F, et al. Phase II, multicenter, uncontrolled trial of singleagent sorafenib in patients with relapsed or refractory, advanced non-small-cell lung cancer. J Clin Oncol 2009; 27(26): 4274-80.

[46] Gutierrez M, Kummar S, Allen D, Turkbey B, Choyke P, Wright J, et al. A phase II study of multikinase inhibitor sorafenib in patients with relapsed non-small cell lung cancer (NSCLC). American Society of Clinical Oncology $-8^{\text {th }}$ annual meeting, Chicago, USA, (2008).

[47] Adjei A, Molina J, Mandrekar S, Marks R, Reid J, Croghan G, et al. Phase I trial of sorafenib in combination with gefitinib in patients with refractory or recurrent non-small cell lung cancer. Clin Cancer Res 2007; 13(9): 2684-91.

[48] Schiller J, Flaherty K, Redlinger M, Binger K, Eun J, Petrenciuc O, et al. Eds. Sorafenib combined with carboplatin/paclitaxel for advanced non-small cell lung cancer: A phase I subset analysis. American Society of Clinical Oncology - $6^{\text {th }}$ annual meeting, Chicago, USA, (2006).

[49] Reck M, Frickhofen N, Gatzemeier U, Fuhr H, Lanzalone S, Lechuga M, et al. Eds. A phase I dose escalation study of sunitinib in combination with gemcitabine+ cisplatin for advanced non-small cell lung cancer (NSCLC). American Society of Clinical Oncology - $7^{\text {th }}$ annual meeting, Chicago, USA, (2007).

[50] Brahmer J, Govindan R, Novello S, Rosell R, Belani C, Atkins J, et al. Eds. Efficacy and safety of continuous daily sunitinib dosing in previously treated advanced non-small cell lung cancer (NSCLC): Results from a phase II study. American Society of Clinical Oncology - $7^{\text {th }}$ annual meeting, Chicago, USA, (2007).

[51] Korpanty G, Smyth E, Sullivan L, Brekken R, Carney D. Antiangiogenic therapy in lung cancer: Focus on vascular 
endothelial growth factor pathway. Exp Biol Med 2010; 235(1): 39.

[52] Schiller J, Larson T, Ou S, Limentani S, Sandler A, Vokes E, et al. Efficacy and safety of axitinib in patients with advanced non-smallcell lung cancer: Results from a phase II study. J Clin Oncol 2009; 27(23): 3836-41

[53] O'reilly, M.S., Folkman, J.M., Abrams, G.S. Therapeutic antiangiogenic endostatin compositions. US7867975 (2011).

[54] Reck M, Kaiser R, Eschbach C, Stefanic M, Love J, Gatzemeier U, et al. A phase II double-blind study to investigate efficacy and safety of two doses of the triple angiokinase inhibitor BIBF 1120 in patients with relapsed advanced non-small-cell lung cancer. Ann Oncol 2011; doi: 10.1093/annonc/mdq618.

[55] Araujo A, Ribeiro R, Azevedo I, Coelho A, Soares M, Sousa B, et al. Genetic polymorphisms of the epidermal growth factor and related receptor in non-small cell lung cancer: A review of the literature. Oncologist 2007; 12(2): 201-10.

[56] Zhu C, da Cunha Santos G, Ding K, Sakurada A, Cutz J, Liu N, et al. Role of KRAS and EGFR as biomarkers of response to erlotinib in National Cancer Institute of Canada Clinical Trials Group Study BR. 21. J Clin Oncol 2008; 26(26): 4268-75.

[57] Miller V, Riely G, Zakowski M, Li A, Patel J, Heelan R, et al. Molecular characteristics of bronchioloalveolar carcinoma and adenocarcinoma, bronchioloalveolar carcinoma subtype, predict response to erlotinib. J Clin Oncol 2008; 26(9): 1472-8.

[58] Choong N, Salgia R, Vokes E. Key signaling pathways and targets in lung cancer therapy. Clin Lung Cancer 2008; 8(suppl 2): 52-60.

[59] Adjei A, Hidalgo M. Intracellular signal transduction pathway proteins as targets for cancer therapy. J Clin Oncol 2005; 23(23): 5386-403.

[60] Toschi L, Cappuzzo F. Understanding the new genetics of responsiveness to epidermal growth factor receptor tyrosine kinase inhibitors. Oncologist 2007; 12(2): 211-20.

[61] Rosell R, Cuello M, Cecere F, Santarpia M, Reguart N, Felip E, et al. Usefulness of predictive tests for cancer treatment. Bull Cancer 2006; 93(8): E101-E08

[62] Sholl L, Xiao Y, Joshi V, Yeap B, Cioffredi L, Jackman D, et al. EGFR Mutation is a better predictor of response to tyrosine kinase inhibitors in non-small cell lung carcinoma than FISH, CISH, and immunohistochemistry. Am J Clin Pathol 2010; 133(6): 922-34.

[63] Zhang Z, Stiegler A, Boggon T, Kobayashi S, Halmos B. EGFRmutated lung cancer: A paradigm of molecular oncology. Oncotarget 2010; 1(7): 497-514.

[64] Shepherd F, Rodrigues Pereira J, Ciuleanu T, Tan E, Hirsh V, Thongprasert S, et al. Erlotinib in previously treated non-small-cell lung cancer. N Engl J Med 2005; 353(2): 123-32.

[65] Lynch T, Bell D, Sordella R, Gurubhagavatula S, Okimoto R, Brannigan B, et al. Activating mutations in the epidermal growth factor receptor underlying responsiveness of non-small-cell lung cancer to gefitinib. N Engl J Med 2004; 350(21): 2129-39.

[66] Ichihara S, Toyooka S, Fujiwara Y, Hotta K, Shigematsu H, Tokumo M, et al. The impact of epidermal growth factor receptor gene status on gefitinib-treated Japanese patients with non-smallcell lung cancer. Int J Cancer 2007; 120(6): 1239-47.

[67] Lind J, Dingemans A, Groen H, Thunnissen F, Bekers O, Heideman D, et al. A Multicenter Phase II study of erlotinib and sorafenib in chemotherapy-naïve patients with advanced non-small cell lung cancer. Clin Cancer Res 2010; 16(11): 3078-87.

[68] Takano T, Ohe Y, Sakamoto H, Tsuta K, Matsuno Y, Tateishi U, et al. Epidermal growth factor receptor gene mutations and increased copy numbers predict gefitinib sensitivity in patients with recurrent non-small-cell lung cancer. J Clin Oncol 2005; 23(28): 6829-37.

[69] Hirsch F, Varella-Garcia M, McCoy J, West H, Xavier A, Gumerlock $\mathrm{P}$, et al. Increased epidermal growth factor receptor gene copy number detected by fluorescence in situ hybridization associates with increased sensitivity to gefitinib in patients with bronchioloalveolar carcinoma subtypes: A Southwest Oncology Group Study. J Clin Oncol 2005; 23(28): 6838-85.

[70] Tracy S, Mukohara T, Hansen M, Meyerson M, Johnson B, Jänne P. Gefitinib induces apoptosis in the EGFRL858R non-small-cell lung cancer cell line H3255. Cancer Res 2004; 64(20): 7241-4.

[71] Krause D, Van Etten R. Tyrosine kinases as targets for cancer therapy. N Engl J Med 2005; 353(2): 172-87.
[72] Mok T, Wu Y, Thongprasert S, Yang C, Chu D, Saijo N, et al. Gefitinib or carboplatin-paclitaxel in pulmonary adenocarcinoma. N Engl J Med 2009; 361(10): 947-57.

[73] Maemondo M, Inoue A, Kobayashi K, Sugawara S, Oizumi S, Isobe $\mathrm{H}$, et al. Gefitinib or chemotherapy for non-small-cell lung cancer with mutated EGFR. N Engl J Med 2010; 362(25): 2380-8.

[74] Mitsudomi T, Morita S, Yatabe Y, Negoro S, Okamoto I, Tsurutan $\mathrm{J}$, et al. Gefitinib versus cisplatin plus docetaxel in patients with non-small-cell lung cancer harbouring mutations of the epidermal growth factor receptor (WJTOG3405): An open label, randomised phase 3 trial. Lancet Oncol 2010; 11(2): 121-28.

[75] Cappuzzo F, Ciuleanu T, Stelmakh L, Cicenas S, Szczésna A, Juhász E, et al. Erlotinib as maintenance treatment in advanced non-small-cell lung cancer: A multicentre, randomised, placebocontrolled phase 3 study. Lancet Oncol 2010; 11(6): 521-9.

[76] Pao W, Miller V, Politi K, Ricly G, Somwar R, Zakowski M, et al. Acquired resistance of lung adenocarcinomas to gefitinib or erlotinib is associated with a second mutation in the EGFR kinase domain. PloS Med 2005; 2(3): 225-35.

[77] Toschi L, Cappuzzo F. Clinical implications of MET gene copy number in lung cancer. Future Oncol 2010; 6(2): 239-47.

[78] Saavedra, O.M., Claridge, S.W., Zhan, L., Raeppel, F., Vaisburg, A., Raeppel, S., Deziel, R., Mannion, M., Zhou, N. Z., Isakovic, L. Inhibitors of VEGF receptor and HGF receptor signaling. US7790729 (2010).

[79] Schiller J, Akerley W, Brugger W, Ferrari D, Garmey E, Gerber D, et al. Eds. Results from ARQ 197-209: A global randomized placebo-controlled phase II clinical trial of erlotinib plus ARQ 197 versus erlotinib plus placebo in previously treated EGFR inhibitornaive patients with locally advanced or metastatic non-small cell lung cancer (NSCLC). American Society of Clinical Oncology $10^{\text {th }}$ annual meeting, Chicago, USA, (2010).

[80] Wakelee H, Gettinger S, Engelman J, Janne P, West H, Subramaniam D, et al. Eds. A phase Ib/II study of XL184 (BMS 907351) with and without erlotinib (E) in patients (pts) with nonsmall cell lung cancer (NSCLC). American Society of Clinical Oncology - $10^{\text {th }}$ annual meeting, Chicago, USA, (2010).

[81] Shinomiya, N., Vande Woude, G.F. c-met siRNA adenovirus vectors inhibit cancer cell growth, invasion and tumorigenicity. US7872117 (2011).

[82] Gatzemeier U, Blumenschein G, Fosella F, Simantov R, Elting J, Bigwood D, et al., Eds. Phase II trial of single-agent sorafenib in patients with advanced non-small cell lung carcinoma. American Society of Clinical Oncology - $6^{\text {th }}$ annual meeting, Chicago, USA, (2006).

[83] Kiura K, Nakagawa K, Shinkai T, Eguchi K, Ohe Y, Yamamoto N, et al. A randomized, double-blind, phase IIa dose-finding study of vandetanib (ZD6474) in Japanese patients with non-small cell lung cancer. J Thorac Oncol 2008;3(4):386-93.

[84] Heymach J, Johnson B, Prager D, Csada E, Roubec J, Pesek M, et al. Randomized, placebo-controlled phase II study of vandetanib plus docetaxel in previously treated non small-cell lung cancer. J Clin Oncol 2007; 25(27): 4270-7.

[85] Heymach JV, Paz-Ares L, De Braud F, Sebastian M, Stewart DJ, Eberhardt WEE, et al. Randomized phase II study of vandetanib alone or with paclitaxel and carboplatin as first-line treatment for advanced non-small-cell lung cancer. J Clin Oncol 2008; 26(33): 5407-15.

[86] Sridhar S, Shepherd F. Targeting angiogenesis: A review of angiogenesis inhibitors in the treatment of lung cancer. Lung Cancer 2003; 42(2): 81-91.

[87] Lee S, Woll P, Rudd R, Ferry D, O'Brien M, Middleton G, et al. Anti-angiogenic therapy using thalidomide combined with chemotherapy in small cell lung cancer: A randomized, doubleblind, placebo-controlled trial. J Nat Cancer Inst 2009; 101(15): 1049-57.

[88] Reck M, von Pawel J, Zatloukal P, Ramlau R, Gorbounova V, Hirsh V, et al. Overall survival with cisplatin-gemcitabine and bevacizumab or placebo as first-line therapy for nonsquamous nonsmall-cell lung cancer: Results from a randomised phase III trial (AVAiL). Ann Oncol 2010; 21(9): 1804-9.

[89] Pirker R. Bevacizumab in lung cancer: Hurdles in clinical development. Lancet Oncol 2010; 11(8): 703-4.

[90] Miller V, O'Connor P, Soh C, Kabbinavar F. A randomized, double-blind, placebo-controlled, phase IIIb trial (ATLAS) comparing bevacizumab (B) therapy with or without erlotinib (E) 
after completion of chemotherapy with B for first-line treatment of locally advanced, recurrent, or metastatic non-small cell lung cancer (NSCLC). American Society of Clinical Oncology - $9^{\text {th }}$ annual meeting, Chicago, USA(2009).

[91] Akerley W, Langer C, Oh Y, Strickland D, Royer S, Xia Q, et al. Acceptable safety of bevacizumab therapy in patients with brain metastases due to non-small cell lung cancer. American Society of Clinical Oncology - $9^{\text {th }}$ annual meeting, Chicago, USA (2008).

[92] Hong, K., Guo, L.S.S., Tseng, Y.L., Song, H.L., Chang, P.C., Shih, S.F. Anti-VEGF monoclonal antibody. US 7740844 (2010).

[93] Fuh, G., Gerber, H.P., Liang, W.C., Fellouse, F.A., Sidhu, S.S., Wiesmann, C. Anti-VEGF antibodies. US 7691977 (2010).

[94] Rosen P, Sweeney C, Park D, Beaupre D, Deng H, Leitch I, et al. A Phase Ib study of AMG 102 in combination with bevacizumab or motesanib in patients with advanced solid tumors. Clin Cancer Res 2010; 16(9): 2677-87.

[95] Moss R, Bothos J, Filvaroff E, Merchant M, Eppler S, Yu W, et al. Phase $\mathrm{Ib}$ dose-escalation study of MetMAb, a monovalent antagonist antibody to the receptor MET, in combination with bevacizumab in patients with locally advanced or metastatic solid tumors. American Society of Clinical Oncology - $10^{\text {th }}$ annual meeting, Chicago, USA, (2010).

[96] Bates, D., Harper, S. VEGF isoforms and their use as antiangiogenic, anti-vasodilatory, anti-permeability and antiproliferative agents. US7820178 (2010).

[97] Stassen, J.M., Carmeliet, P., Collen, D. Anti-PLGF antibody. US7875704 (2011)

[98] Laino C. NSCLC: MetMAb ${ }^{+}$erlotinib extends survival in subset of lung cancer patients. Oncology Times 2010; 32(24): 38-39.

[99] Ciardiello F, Jezdic S. New insights on personalized cancer treatments: A report from the ESMO Congress. Expert Rev Anticancer Ther 2011; 11(1): 21-23.

[100] Dy G, Adjei A. Novel targets for lung cancer therapy: Part I. J ClinOncol 2002; 20(12): 2881-94

[101] Jain L, Vargo CA, Danesi R, Sissung TM, Price DK, Venzon D, et al. The role of vascular endothelial growth factor SNPs as predictive and prognostic markers for major solid tumors. Mol Cancer Ther 2009; 8(9): 2496-508.

[102] Vidaurreta M, Sánchez-Muñoz R, Veganzones S, Rafael S, Gutiérrez M, de la Orden V, et al. Vascular endothelial growth factor gene polymorphisms in patients with colorectal cancer. Rev Esp Enferm Dig 2010; 102(1): 20-31.

[103] Zhai R, Liu G, Zhou W, Su L, Heist R, Lynch T, et al. Vascular endothelial growth factor genotypes, haplotypes, gender, and the risk of non-small cell lung cancer. Clin Cancer Res 2008; 14(2): 612-7.

[104] Balasubramanian S, Brown N, Reed M. Role of genetic polymorphisms in tumour angiogenesis. Br J Cancer 2002; 87(10): 1057-65.
[105] Howell W, Bateman A, Turner S, Collins A, Theaker J. Influence of vascular endothelial growth factor single nucleotide polymorphisms on tumour development in cutaneous malignant melanoma. Genes Immun 2002; 3(4): 229-32.

[106] McCarron S, Edwards S, Evans P, Gibbs R, Dearnaley D, Dowe A et al. Influence of cytokine gene polymorphisms on the development of prostate cancer. Cancer Res 2002; 62(12): 3369-72.

[107] Koukourakis M, Papazoglou D, Giatromanolaki A, Bougioukas G, Maltezos E, Siviridis E. VEGF gene sequence variation defines VEGF gene expression status and angiogenic activity in non-small cell lung cancer. Lung Cancer 2004; 46(3): 293-98.

[108] Heist RS, Zhai R, Liu G, Zhou W, Lin X, Su L, et al. VEGF polymorphisms and survival in early-stage non-small-cell lung cancer. J Clin Oncol 2008; 26(6): 856-62.

[109] Bieniasz M, Oszajca K, Eusebio M, Kordiak J, Bartkowiak J, Szemraj J. The positive correlation between gene expression of the two angiogenic factors: VEGF and BMP-2 in lung cancer patients. Lung Cancer. 2009; 66(3): 319-26.

[110] Dong J, Dai J, Shu Y, Pan S, Xu L, Chen W, et al. Polymorphisms in EGFR and VEGF contribute to non-small cell lung cancer survival in a Chinese Population. Carcinogenesis 2010; 31(6): 1080-6.

[111] Lee SJ, Lee SY, Jeon HS, Park SH, Jang JS, Lee GY, et al Vascular endothelial growth factor gene polymorphisms and risk of primary lung cancer. Cancer Epidemiol Biomarkers Prev 2005; 14(3): $571-5$

[112] Masago K, Fujita S, Kim Y, Hatachi Y, Fukuhara A, Nagai H, et al. Effect of vascular endothelial growth factor polymorphisms on survival in advanced stage non small cell lung cancer. Cancer Sci 2009; 100(10): 1917-22.

[113] Watson C, Webb N, Bottomley M, Brenchley P. Identification of polymorphisms within the vascular endothelial growth factor (VEGF) gene: Correlation with variation in VEGF protein production. Cytokine 2000; 12(8): 1232-35.

[114] Shahbazi M, Fryer A, Pravica V, Brogan I, Ramsay H, Hutchinson I, et al. Vascular endothelial growth factor gene polymorphisms are associated with acute renal allograft rejection. J Am Soc Nephrol 2002; 13(1): 260-4.

[115] Stevens A, Soden J, Brenchley P, Ralph S, Ray D. Haplotype analysis of the polymorphic human vascular endothelial growth factor gene promoter. Cancer Res 2003; 63(4): 812-6.

[116] Inoue A, Kobayashi K, Usui K, Maemondo M, Okinaga S, Mikami I, et al. First-line gefitinib for patients with advanced non-smallcell lung cancer harboring epidermal growth factor receptor mutations without indication for chemotherapy. J Clin Oncol 2009; 27(9): 1394-400.

[117] Brundage M, Davies D, Mackillop W. Prognostic factors in nonsmall cell lung cancer. Chest 2002; 122(3): 1037-57. 